\title{
Botulinum Toxin A in Patients with Chronic Migraine: A Single-Center Experience
}

\section{Kronik Migrenli Hastalarda Bir Kliniğin Botulinum Toksin A Deneyimi}

\author{
Şükran Ç. Yurtoğulları' \\ 'Clinic of Neurology, Atatürk Training and Research Hospital, Ankara, Turkey
}

\begin{abstract}
Objective: The Botulinum toxin A (BoNT/A), increasingly used in many fields in recent years, was shown to be effective in chronic migraine $(\mathrm{CM})$ in recent studies. In this study, we aimed to investigate treatment response in our CM patients who underwent BoNT/A therapy.

Material and Method: The study included $41 \mathrm{CM}$ patients (aged 18-65 years). We questioned patients undergoing BoNT/A therapy regarding demographic characteristics, education level, time of diagnosis, migraine triggers, and previous therapies at first visit prior to injection. The patients were assessed together with analgesic use, visual analog scale (VAS) score and Migraine Disability Assessment Score (MIDAS) rating at month 6 after treatment.
\end{abstract}

Results: There were 36 women (87.8\%) and 5 men (12.2\%) in the study group. Mean age was calculated as $44.88 \pm 10.51$ years. Of the patients, 20 patients (48.8\%) fulfilled criteria for migraine with aura while no aura was detected in 21 patients (51.2\%). Significant decrease was detected in MIDAS rating and VAS scores after BoNT/A therapy $(p<0.001)$.

Conclusion: The BoNT/A was found to be effective and safe in the prophylactic treatment of chronic migraine. The BoNT/A is a potent treatment that could be performed by experienced neurologists in eligible CM patients regardless of previous prophylactic treatments.

Keywords: Headache, chronic migraine, Botilinum toxin A
Öz

Amaç: Son yıllarda her alanda kullanımı artan Botulinum toksin A (BoNT/A)'nın yapılan son çalışmalarla etkinliği kronik migrende de (KM) gösterilmiştir. Nöroloji kliniklerinde de uzun yıllardır Fokal Distoniler, Distoni olmayan istemsiz hareket bozuklukları, Spastisite, Otonom Sinir Sistemi bozuklukları gibi kullanımlardan sonra KM de kullanımı hızla yayılmaktadır. Bizde bu çalışmamız ile KM tanısıyla takip ettiğimiz BoNT/A uygulanan hastalarımızın tedavi yanıtlarını incelemeyi amaçladık.

Gereç ve Yöntem: Kronik Migren tanılı, ülkemizdeki ruhsatlı tedavi seçeneklerini kulanmış olmasına rağmen yeterli yanıt alınamayan, 1865 yaş arası ve ek nörolojik hastalığı olmayan 41 Kronik Migren (KM) hastası çalışmaya dahil edildi. BoNT/A tedavisi alan hastalar enjeksiyon öncesi ilk vizitlerinde demografik bilgiler (yaş,cinsiyet), eğitim durumu, tanı zamanı, migren tetikleyicileri, aldıkları tedaviler açısından sorgulandı ve tedavi sonrası altıncı aylarında analjezik kullanımı, atak sıklığı, VAS (Vizuel Analog Skala) ve MIDAS (Migren Özürlülük Değerlendirmesi) skorları ile birlikte değerlendirildi.

Bulgular: Hastaların 36 (\%87.8) kadın, 5 (\%12.2) erkekti. Yaş ortalaması $44.88 \pm 10.51$ olarak saptandı. Migren hastalık süresi ortalama 15.75 yı idi. Hastaların 25 (\%61)'inde birinci derece akrabalarında aile öyküsü varken 16 (\%39) hastada yoktu. Hastaların 20 (\%48.8)'i auralı migren kriterlerine sahipken, 21(\%51.2)'inde aura saptanmadı. Hastaların BoNT/A tedavisi sonrası MIDAS ve VAS skorlarında anlamlı düşme saptandı $(p<0.001)$

Sonuç: Botulinum Toksin A tedavisi KM'nin proflaktik tedavisinde etkin ve güvenilir bulunmuştur. Hastaların migrene bağlı özürlülüğünün azaldığı ve yaşam kalitesinin arttırdığı saptanmıştır.. Tüm proflaksi tedavilerini alan KM'li uygun kriterli hastalarda BoNT/A deneyimli nöroloji uzmanlarınca uygulanacak güçlü bir tedavidir.

Anahtar Kelimeler: Baş ağrısı, kronik migren, Botilinum toxin A 


\section{INTRODUCTION}

Chronic migraine is a common neurological disorder characterized by severe headache experienced $>15$ days per month over 3 months and headache characteristics fulfilling diagnostic criteria for migraine in at least 8 days of a month, which can impair quality of life severely. ${ }^{[1]}$

According to a population-based epidemiological study from Turkey (2012), migraine is most commonly seen between 20 and 50 years of age with a prevalence of $16.4 \%$. Approximately $10 \%$ of patients with migraine suffer from chronic migraine. ${ }^{[2]}$

The CM prevalence varies from $2.5 \%$ to $5.5 \%$ in different studies. In a comprehensive study on CM epidemiology from USA, prevalence was estimated as $2 \% .^{[3]}$

The Botulinum toxin A (BoNT/A), increasingly used in many fields in recent years, was shown to be effective in chronic migraine (CM) in recent studies. ${ }^{[4-6]}$ The use of BoNT/A in CM has been rapidly growing following its use over many years in the treatment of focal dystonia, non-dystonic movement disorders, spasticity, autonomic nervous system disorder in neurology clinics.

The prophylactic use of BoNT/A in CM was approved by The United States Food and Drug Administration (FDA) in 2010 and American Neurology Academy guidelines suggest that it is an effective treatment and should be recommend to $\mathrm{CM}$ patients in this setting. ${ }^{[7]}$ The National Institute for Health and Care Excellence (NICE) recommends BoNT/A as a prophylactic option in CM patients unresponsive to at least 3 pharmacological prophylactic trials. ${ }^{[8]}$ The botulinum neurotoxin (BoNT) is a protein complex produced by Clostridium botilinum, a gram-positive anaerobic bacterium. Although it has 7 different serotypes, only two are available for clinical use. ${ }^{[9]}$ Mechanism of action involves inhibition of acetylcholine from presynaptic vesicles at neuromuscular junction, resulting dose-dependent, reversible muscle paralysis. ${ }^{[10]}$

The BoNT exert maximum effect 2 weeks after application and its effect is abolished by axonal budding after 4-6 months. However, it is difficult to explain its effect on pain by this mechanism; it is thought that BoNT/A inhibits peripheral sensitization of nociceptive fibers; thus, decreasing central sensitization. ${ }^{[1]]}$ In many studies, it was shown that BoNT/A inhibited substance $P$, glutamate $A$ and calcitonin gene-related peptide which are among major mediators of inflammatory pain and released from activated sensorial nerve terminals. ${ }^{[12-15]}$ It is thought that such inhibition prevents neurogenic inflammation and peripheral sensitization, resulting in decrease in pain signals transmitted to central nervous system from periphery. Thus, the BoNT/A indirectly blocks central sensitization seen in migraine and other painful conditions. ${ }^{[16,17]}$

Chronic migraine is a common neurological disorder that adversely influences quality of life, which is most common cause of chronic, daily headache. The effective treatment of disease can improve performance in both professional and personal life. We aimed to demonstrate effectiveness of BoNT/A (with proven effectiveness in pain) on intense pain in $\mathrm{CM}$ patients and present treatment responses of our CM patients treated with BoNT/A in our clinic.

\section{MATERIAL AND METHOD}

This is a single-center, prospective study. The study included 41 patients without comorbid neurological disorder (aged 18-65 years) who presented to neurology outpatient clinic with headache between January, 2016 and January, 2019 and diagnosed as chronic migraine according to 2004 International Headache Society (IHS) diagnostic criteria and underwent BoNT/A therapy as they did not respond all therapeutic options approved in Turkey (tolerance to agents used or unresponsiveness to prophylactic agent used over 2 months).

Patients with history of head-neck surgery, drug overdose ( $\geq 15$ simple analgesics or $>10$ combined analgesics and/ or tryptophan use in prior 3 months) and pregnant or breastfeeding women were excluded from study.

As recommended in PREMPT studies ${ }^{[4-6]}$, BoNT/A (5 units per region; overall 155 units) was administered as to 31 points in 7 anatomic regions (corrugator, proserus, frontalis, temporalis, occipital, paraspinal and trapezius muscle groups).

To rule out secondary pathologies, biochemical assays, complete blood count, thyroid function tests, vitamin B12, folic acid and vitamin D levels as well as cranial imaging studies after diagnosis of CM were evaluated.

In our country, the BoNT/A is not in repayment coverage despite approved for use in CM, Off-Label Drug Consent forms were completed as cited in website of Health Ministry. The BoNT/A therapy was given to patients in whom treatment was approved based on defined criteria. The patients were assessed in visits at baseline and on month 6 after BoNT/A therapy. In first visit, the patients were questioned in detail regarding demographic data (age, gender), education level, time of diagnosis, migraine triggers and previous treatments. In addition analgesic use, attack frequency, VAS and MIDAS scores were assessed at baseline and on month 6 . All patients gave written informed consent. The study was approved by Ethics Committee of Ankara City Hospital (protocol no: 2019E-19-083).

\section{Statistical Analysis}

All statistical analyses were performed by SPSS (Statistical Package for Social Sciences) for Windows version 20.0. The normal distribution of numerical data was assessed by Shapiro-Wilk test. Continuous variables were defined as mean, standard deviation and min-max. Non-parametric Wilcoxon test was used to compare repeated measurements. A p value $<0.05$ was considered as statistically significant. 


\section{RESULTS}

There were 36 women (87.8\%) and 5 men (12.2\%) in the study group. Mean age was calculated as $44.88 \pm 10.51$ years ranging from 20 to 64 years (Table 1). The family history in first-degree relatives was positive in 25 patients (61\%) while it was negative in 16 patients (39\%). Of the patients, 20 patients (48.8\%) fulfilled criteria for migraine with aura while no aura was detected in 21 patients (51.2\%).

Table 1. Age and gender distribution of patients.

\begin{tabular}{|c|c|c|c|c|c|c|}
\hline \multirow{2}{*}{ Gender } & \multirow{2}{*}{$\mathbf{n}$} & \multirow{2}{*}{$\%$} & \multicolumn{4}{|c|}{ Age (years) } \\
\hline & & & Max & Min & Mean & SD \\
\hline Male & 5 & 12.2 & 56 & 20 & 43.6 & 10.5 \\
\hline Female & 36 & 87.8 & 64 & 23 & 45.05 & 10.5 \\
\hline Total & 41 & 100 & 64 & 20 & 44.88 & 10.5 \\
\hline
\end{tabular}

Significant decreases were detected in attack frequency, attack duration, number of painful days, VAS score and MIDAS rating on month 6 after BoNT/A therapy when compared to baseline $(p<0.001)$. The mean pain intensity was found as $8.72 \pm 1.01$ ranging from 5 to 10 before treatment while it was found as $5.85 \pm 2.27$ ranging from 0 to 9 after BoNT/A therapy (Table 2). The MIDAS rating was 1 in 7 patients, 2 in 4 patients, 3 in 8 patients and 4 in 22 patients before BoNT/A therapy while it was 1 in 26 patients, 2 in 11 patients, in 3 patients and 4 in one patient after therapy (Table 3 ).

The main migraine triggers were light, sound and smell found in 32 patients; followed by hunger, stress and insomnia (Figure 1). There were 14 patients underwent trial with traditional and complementary medicine interventions which have become popular in Turkey in recent years. Before presentation, 4 patients underwent acupuncture therapy while 10 patients underwent cupping.

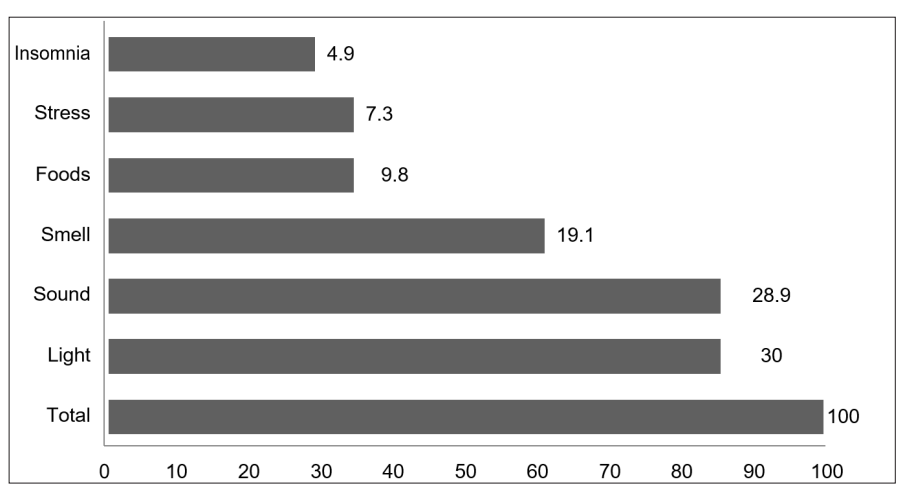

Figure 1. Migraine disease triggers. Data are presented as percent

\section{DISCUSSION}

The effectiveness of BoNT/A, which is first shown to have analgesic effect in patients with spasmodic torticollis, on migraine was detected after its application to facial hyperfunctional lines. ${ }^{[18]}$ Subsequently, the BoNT/A was introduced in use in many fields and its effectiveness on patients with CM was established in phase III studies in 2010. ${ }^{[19]}$

It has been suggested that migraine frequency is approximately 2-folds greater in reproductive women than men and that attacks are more severe in women. ${ }^{[20]}$ In our study, 36 of 41 patients were women. VAS scores before BoNT/A therapy were found to be higher in female subjects in our study.

It has been suggested that there is positive family history in $45-70 \%$ of patients with migraine headache. ${ }^{[21]}$ In our study, 25 patients $(61 \%)$ had positive migraine history in first-degree relatives, $70 \%$ of which has diagnosis of migraine.

In the literature, it was reported that aura was observed in about one-third of patients with migraine as visual aura being most common type. ${ }^{[22]}$ In our study, aura was defined in 20 Table 2. Migraine characteristics, attack frequency, attack duration, number of painful days, pain severity and disability degree.

\begin{tabular}{|c|c|c|c|c|c|c|c|c|c|c|}
\hline \multirow{2}{*}{$\mathrm{N}=41$} & \multicolumn{4}{|c|}{ Before BoNT/A } & \multicolumn{4}{|c|}{ After BoNT/A } & \multicolumn{2}{|c|}{ Wilcoxon signed- rank tes } \\
\hline & Mean & SD & Min & Max & Mean & SD & Min & Max & $\mathbf{z}$ & $\mathbf{p}$ \\
\hline Monthly Migraine Attack & 11.95 & 6.12 & 5 & 30 & 4.90 & 4.49 & 0 & 20 & -4.994 & $<0.001$ \\
\hline Pain duration (hour) & 23.66 & 17.99 & 6 & 72 & 6.34 & 7.13 & 0 & 24 & -5.446 & $<0.001$ \\
\hline Number of painful days (month) & 17.63 & 5.80 & 8 & 30 & 5.24 & 5.31 & 0 & 24 & -5.515 & $<0.001$ \\
\hline VAS & 8.72 & 1.01 & 5 & 10 & 5.85 & 2.27 & 0 & 9 & -5.135 & $<0.001$ \\
\hline MIDAS & 24.90 & 16.08 & 2 & 54 & 4.46 & 5.13 & 0 & 25 & -5.513 & $<0.001$ \\
\hline
\end{tabular}

Table 3. Migraine Disability Assessment Score (MIDAS) score before and after Botulinum Toxin A (BoNT/A) therapy.

\begin{tabular}{|c|c|c|c|c|}
\hline Disability state & $\begin{array}{c}\text { Number of patients before } \\
\text { BoNT/A therapy (n) }\end{array}$ & Rate (\%) & $\begin{array}{c}\text { Number of patients after } \\
\text { BoNT/A therapy (n) }\end{array}$ & Rate (\%) \\
\hline MIDAS-I (0-5 points) & 7 & 17.1 & 26 & 63.4 \\
\hline MIDAS-II (6-10 points) & 4 & 9.8 & 11 & 26.8 \\
\hline MIDAS-III (11-20 points & 8 & 19.5 & 3 & 7.3 \\
\hline MIDAS-IV ( $\geq 21$ points) & 22 & 53.7 & 1 & 2.4 \\
\hline TOPLAM & 41 & 100 & 41 & 100 \\
\hline
\end{tabular}


patients (48.8\%). Aura was defined as visual aura in 8 patients (40\%); followed by visual-sensorial and visual-vertiginous aura. In a double-blinded, placebo-controlled study by Freitag et al., BoNT/A $(n=21)$ and placebo $(n=20)$ was administered to fixed injection points at fixed doses and it was found that BoNT/A therapy was superior to placebo. ${ }^{[23]}$

The BoNT/A effectiveness was confirmed in many studies conducted after FDA approval, as our study did. Similarly, it was observed that there were decreases in pain severity, number of days with headache and migraine disability. ${ }^{[24-26]}$

In a study by Elif Ilgaz et al., in which MIDAS rating and pain scores were assessed at baseline and on weeks 12 and 24 after BoNT/A therapy, it was suggested that MIDAS ratings was improved upon first dose with marked improvement in pain frequency and severity. ${ }^{[27]}$

Previous studies showed that BoNT/A is well-tolerated by patients with chronic migraine. In addition, it was found that treatment discontinuation due to adverse effects was significantly rare (1.4-3.8\%). ${ }^{[28]}$ In our study, there was neck pain in 1 patient and mild pain not requiring analgesic use and lasting less than 24 hours at injection site in 4 patients. No treatment discontinuation was observed. It was shown that treatment discontinuation rate is $12.7 \%$ in oral prophylaxis regimes. ${ }^{[29]}$ BoNT/A therapy seem to be a good alternative in this regard.

Some patients with migraine define no trigger for onset of headache. However, stress, light, smell, menstruation, sleep disorders, hunger (skipping a meal), change of air, alcohol (wine and beer in particular) and some foods may trigger migraine. ${ }^{[30]}$ In our study, there was one or more migraine triggers in $78.04 \%$ of our patients.

\section{CONCLUSION}

It is well-known that migraine is a common neurological disorder that adversely affects social and professional life of individuals. Many drugs and traditional modalities have been used as prophylactic therapy in patients with chronic migraine. The BoNT/A is a novel therapeutic modality in the treatment of migraine which may be triggered by lifestyle, comorbid conditions and eating habits. BoNT/A was found to be effective and safe in the prophylactic treatment of chronic migraine. It was also found that migraine-related disability was decreased with improving quality of life. BoNT/A is a potent treatment that could be performed by experienced neurologists in eligible CM patients regardless of previous prophylactic treatments.

\section{ETHICAL DECLARATIONS}

Ethics Committee Approval: The study was approved by Ethics Committee of Ankara City Hospital (protocol no: 2019E-19-083).

Informed Consent: All patients signed the free and informed consent form.
Referee Evaluation Process: Externally peer-reviewed. Conflict of Interest Statement: The authors have no conflicts of interest to declare.

Financial Disclosure: The authors declared that this study has received no financial support.

Author Contributions: All of the authors declare that they have all participated in the design, execution, and analysis of the paper, and that they have approved the final version.

\section{REFERENCES}

1. Headache Classification Committee of the International Headache Society (2013) The international classification of headache disorders, 3rd edition (beta version). Cephalalgia 33:629-808. DOI: 10.1177/0333102413485658

2. Ertas M, Baykan B, Kocasoy Orhan E, et al. One-year prevalence and the impact of migraine and tension-type headache in Turkey: a nation wide home-based study in adults. J Headache Pain 2012; 13:147-157. DOI: 10.1007/s10194-011-0414-5.

3. Lipton RB, Bigal ME, Diamond M, et al; AMPP Advisory Group. Migraine prevalence, disease burden, and the need for preventive therapy. Neurology 2007; 68:343-349. DOI:10.1212/01.wnl.0000252808.97649.21

4. Blumenfeld A, Silberstein S, Dodick D, et al. (2010) Method of injection of OnabotulinumtoxinA for chronic migraine: a safe, well-tolerated, and effective treatment paradigm based on the PREEMPT clinical program. Headache 50: 1406-1418. DOI:10.1111/j.1526-4610.2010.01766.x

5. Diener H, Dodick D, Aurora S, et al. (2010) OnabotulinumtoxinA for treatment of chronic migraine: results from the double-blind, randomized, placebo-controlled phase of the PREEMPT 2 trial. Cephalalgia 30: 804814. DOI:10.1177/0333102410364677

6. Lipton R, Rosen N, Ailani J, et al. (2016) OnabotulinumtoxinA improves quality of life and reduces impact of chronic migraine over one year of treatment: pooled results from the PREEMPT randomized clinical trial program. Cephalalgia 36: 899-908. DOI: 10.1177/0333102416652092

7. Simpson D, Hallett M, Ashman E, et al. (2016) Practice guideline update summary: botulinum neurotoxin for the treatment of blepharospasm, cervical dystonia, adult spasticity, and headache: report of the Guideline Development Subcommittee of the American Academy of Neurology. Neurology 86: 1818-1826. DOI: 10.1212/WNL.0000000000002560.

8. Botulinum Toxin Type A for the Prevention of Headaches in Adults with Chronic Migraine. NICE (2012) Technology appraisal guidance [TA260] Available at: https://www.nice.org.uk/Guidance/ta260.

9. Bigalke $H$, Botulinum toxin: application, safety, and limitations.Curr Top Microbiol Immunol. 2013;364:307-17. DOI:10.1007/978-3-642-335709_14

10. Dolly O. Synaptic transmission: inhibition of neurotransmitter release by botulinum toxins. Headache 2003; 43:16-24. DOI:10.1046/j.15264610.43.7s.4.x

11. Aoki KR. Pharmacology and immunology of botulinum neurotoxins. Int. Ophtalmol Clin 2005; 45:25-37. DOI:10.1097/01.iio.0000167167.10402.74

12. Cui M, Khanijou S, Rubino J, Aoki KR. Subcutaneous administration of botulinum toxin A reduces formalin-induced pain. Pain 2004; 107:125133. DOI:10.1016/j.pain.2003.10.008

13. Meng J, Wang J, Lawrence G, Dolly JO. Synaptobrevin I mediates exocytosis of CGRP from sensory neurons and inhibition by botulinum toxins reflects their anti-nociceptive potential. J Cell Sci 2007; 120:28642874. DOI:10.1242/jcs.012211

14. Gazerani P, Staahl C, Drewes AM, Arendt-Nielsen L. The effects of Botulinum Toxin type A on capsaicin-evoked pain, flare, and secondary hyperalgesia in an experimental human model of trigeminal sensitization. Pain 2006; 122:315-325. DOI:10.1016/j.pain.2006.04.014

15. Gazerani P, Pedersen NS, Staahl C, Drewes AM, Arendt-Nielsen L. Subcutaneous Botulinum toxin type $A$ reduces capsaicin-induced trigeminal pain and vasomotor reactions in human skin. Pain 2009; 141:60- 69. DOI:10.1016/j.pain.2008.10.005 
16. Durham PL, Cady R, Cady R. Regulation of calcitonin gene-related peptide secretion from trigeminal nerve cells by botulinum toxin type $A$ : implications for migraine therapy. Headache 2004; 44:35-42. DOI:10.1111/ j.1526-4610.2004.04007.x

17. Welch MJ, Purkiss JR, Foster KA. Sensitivity of embryonic rat dorsal root ganglia neurons to Clostridium botulinum neurotoxins. Toxicon 2000; 38:245-258. DOI:10.1016/s0041-0101(99)00153-1

18. Cernuda-Morollón E, Martínez-Camblor P, Ramón C, et al. (2014) CGRP and VIP levels as predictors of efficacy of onabotulinumtoxin type $A$ in Chronic Migraine. Headache 54: 987-995. DOI:10.1111/head.12372

19. Dodick DW, Turkel CC, DeGryse RE, et al; PREEMPT Chronic Migraine Study Group. Onabotulinumtoxin A for treatment of chronic migraine: pooled results from the double-blind, randomized, placebo-controlled phases of the PREEMPT clinical program. Headache 2010; 50:921-36. DOI:10.1111/ j.1526-4610.2010.01678.x

20. Lipton RB, Stewart WF, Diamond S, Diamond ML, Reed M. Prevelance and Burden of Migraine in the United States: Data from the American Migraine Study II. Headache 2001;41:646-657. DOI:10.1046/j.15264610.2001.041007646.x

21. Russell MB, Fenger $\mathrm{K}$, Olesen J. The family history of migraine. Direct versus indirect information. Cephalalgia 1991;11:156-60. DOI:10.1046/ j.1468-2982.1996.1603156.x

22. Smetana GW. The Diagnostik Value Of Historical Features in Primary Headache Syndromes A Comprehensive Review. Arch Intern Med. 2000; 160:2729-2737. DOI:10.1001/archinte.160.18.2729

23. Freitag FG, Diamond $S$, Diamond $M$, Urban G. Botulinum toxin type $A$ in the prophylactic treatment of choronic migraine without mediacation overuse. Headache 2008; 48:201-209. DOI: 10.1111/j.15264610.2007.00963.x

24. Cernuda-Morollón E, Martínez-Camblor P, Ramón C, et al. (2014) CGRP and VIP levels as predictors of efficacy of onabotulinumtoxin type $A$ in Chronic Migraine. Headache 54: 987-995. DOI:10.1111/head.12372

25. Khalil M, Zafar H, Quarshie V, Ahmed F. (2014) Prospective analysis of the use of OnabotulinumtoxinA (BOTOX) in the treatment of chronic migraine; real-life data in 254 patients from Hull, UK J Headache Pain 15: 54. DOI:10.1186/1129-2377-15-54

26. Russo M, Manzoni G, Taga A, et al. (2016) The use of onabotulinum toxin A $\left(\right.$ Botox $\left.^{\oplus}\right)$ in the treatment of chronic migraine at the Parma Headache Centre: a prospective observational study. Neurol Sci 37: 1127-11312022. DOI:10.1007/s10072-016-2568-z

27. Aydınar El, Yalınay Dikmen P, Sağduyu Kocaman A. Botulinum Toxin in Migraine Treatment Noropsikiyatri Arşivi 2013; 50 Ozel Sayı 1: 36-40. Doi: 10.4274/npa.y7198

28. Tsui J, Eisen A, Stoessl A, Calne S, Calne D. (1986) Double-blind study of botulinum toxin in spasmodic torticollis. Lancet 2: 245-247. DOI:10.1016/ s0140-6736(86)92070-2

29. Mathew NT. The prophylactic treatment of chronic daily headache. Headache 2006; 46:1552-64. DOI:10.1111/j.1526-4610.2006.00621.x

30. Özturan A, Şanlıer N, Coşkun Ö. The Relationship Between Migraine and Nutrition. Turk J Neurol 2016;22:44-50. DOI:10.4274/tnd.37132 